\title{
As Postmodern Journalism Citizen Journalism
}

\author{
$1^{\text {st }}$ Nova Darmanto ${ }^{1}, 2^{\text {nd }}$ Santi Delliana ${ }^{2}$ \\ \{nova.darmanto@polimedia.ac.id ${ }^{1}$, anastasia.santi@kalbis.ac.id ${ }^{2}$ \} \\ Politeknik Negeri Media Kreatif, Jakarta, Indonesia ${ }^{1}$, Institut Teknologi dan Bisnis Kalbis, Jakarta, \\ Indonesia $^{2}$
}

\begin{abstract}
Citizens' journalism does not evolve differently from that of digital networking; the quality of journalism is inseparable from technical innovations. Today ICT s are increasingly growing and characterized by online media. The Web is becoming a digital network that promotes computer controlled media include. The advent of the Internet, the technology that underpins this communication, influenced the rapid growth of news and journalism. Civic journalism was developed as a result of the growth of online media. Digital journalism is a framework for the concept of citizens' journalism, where alternative media is a process that no longer employs human or manual resources. Digital systems are designed for analog systems. Digitalisation appears to be a digital operating system computer-readable. The term postmodern journalist refers to contemporary journalism. The revolution isn't always an opport unity. The changes from contemporary to post-modern are progressive in a process which lasts many periods and times. In postmodernism peers who have contributed to centralizing and universalizing concepts in many scientific and technical fields are important.
\end{abstract}

Keywords: citizen journalism, new media, postmodernism.

\section{Introduction}

Our ears are increasingly familiar with Community Journalism or Citizen Journalism. This is different from the growth of digital technology, which enables people to submit information to traditional mass media such as TV, radio, and the Internet, such as YouTube, Forums, Facebook, and Twitter - owing to technicaladvances. Citizen journalis m extends all over the world and also explores people's fields and produces different habits and characteristics.

The growth of civic journalis m is inseparable from new trends in the media. Most men name-new media. The presence, firstly, as digital media are seen as a sign of the progression of the conditions known as modernity towards postmodernity, is inseparable from those of transition. Secondly, the sustainable globalization dynamics, in which the online media is noticeable as an itemthat transcends a country's regional borders through trade, enterprise, and society. Thirdly, with production in the industrial revolution, when social media represented modifications in processes in industries and replaced them in Western Europe by the afterindustrial age, thes pectrumofinnovation was not restricted to production issues but also to changes in market models. Fourthly, decentralization, a new modern, diverse, and capable communication network that can crack the western hegemony, in technology, trade, and distribution, since the colonial period.

This same idea of citizen journalis mis indivisible fromeither the growth of the media. The age of paperlessness was not yet widespread. Technology that is currently emerging has 
reduced paper u sage — data s torage and the digitalization of each paper-formed text. Growing paper is more digital technology-friendly and av ailable, and can be transferred through digital technologies. In various fields of life, technical advances have moved. All those who work there, es pecially in this age, must notbe blinded to innovation, be able to play with the writer and recognize advancement. The goal is to deal with innovations from occasionally.

With the introduction of internet, innovation focused on communications has had an important influence on rapid change in communication industries, es pecially journalism and journalis ts. The Web has transformed linear (yet another way), using skills to accomplish three mains treammedia (radio, TV and print). Online media, too, are modern media. Digital media is an amazing technology which material is distributed through the use of a variety of electronic data, text , s ound and images through a diverse variety of cable, satellite and ultrasound waves transmis sion systems [1].

The internet is a worldwide systemand it has become a sign of change in the perception of digital media today. The digital media has emerged as a new piece of communication, a new type of media which has resurrected a new model for journalism. However, different technologies and functions are far away from pre-existing mainstream journalism. This new kind of press is a new kind of media. The unique nature of the online journalismfunction is that its technology limits on the processing of and dis semination of news online journalism.

The news no longer has been an occurrence, but the media broadcast an ongoing operation through onlinemedia. No story thatcan price it well any more must find in any online media. All the information can use it as news without being proportionate directly to modern media rules. The Internet therefore becomes noticeable as a means of providing results quickly than records. The Internet often transforms the environment and network of media and journalism thru the promotion of citizen journalis $m$.

The control of information access has changed from media outlets to individual and municipalauthorities. In his post, according to $\mathrm{Wu},[2, \mathrm{p} .1]$, today, the $\mathrm{Web}$ has provided media with new problems and benefits. In comparison to the press, we know how digital media are sometimes correlated with declines is what many people term a "crisis" inside the study. McChesney \& Nichols according, [3] in Wu [2, p. 1], The Internet leads to the problem, drawing viewers and rivals to online outlets, which is most endangering conventional (modernist) media business model. The growth of uncheckable online content is als o harmful to democracy. On the other hand, socialmedia and the internet have produced more interested people who are not or will not be covered by traditional media in order to explore online is sues.

In an essay in Wu journal [2, p. 1], At the beginning of the 21st century, McChesney described the decline in journalism. Citizen journalis $m$ is targeted slowly at replacing the position of mas s media, gaining citizens' interest, and exchanging information. That journalis $m$ is dominated notjust by the free press, butals oby ordinary people, for interpretation. Familiar people will produce and disseminate their news through their instruments. Indeed, the rise of citizen journalis mas a res ponse to modern (conventional) Journalism, owing to widespread resentment against the mainstream media.

Wu explained how all influences in the narrative's journal of information, communications, and social media coverages were acceptable: the 2008 contraction, growing use of the Internet, evolving media consumption or viewer tastes, growing media marketing, growth of media ownership and a lack of trust in the main stream media. About the fall of reporters [3]. 


\section{Literature Review}

\section{The Exposure to Knowledge Change}

Digital technology has ceased to use manual or human power. The development of analog sys tems consists of digital orders. Digitalization is usually an automatic operating system with a computer-readable format. Thurtlow [4,p. 36] says the advancement of information technology (Internet), facilitating people to interact almost instantaneously over greater distances, gradually raising the world more rapidly and faster than it has ever been.

Alterations to digital technology have revolutionized several different ways and challenge the survival of other mas s media. Biagi $[5$, p. 10] addresses three main mas s media concepts: first, mass media is a profit-oriented mode of exchange. Second, technical advances are affected by innovations and improvements in the production and us age of mas s media. Third, mains treammedia are also a product of the daily life, politics and society and affect themselves. News media have a huge effect on literacy in all of the above. It is indeed obvious.

Currently, however, almost all of the mass media consumers are using mobile digital platforms and can still read the current content. More vivid appearance attracted advertisements. As mentioned by Messaris and Humphreys [6, p. 201] Print media can be used just when they are physically in the reader's hands. TV can be seen only if consumers are physically positioned In front of the show. The digital age, nevertheless, enables the copying of media material on a related behavior without physical or broadcasting limitation at or at minimal price without any negligible consistency. Unending replication undermines busines $\mathrm{s}$ models of media outlets, which use the selling of replicated ing redients to create profits.

New and exis ting media convergence: modern media reporting, then according Chao Chen, in his article, [7,p. 186] The word "inline" in thedigital age has also become Convergence a guide for rapid technological changes. In the formof Convergence, technological developments have eliminated industry gaps. All the content is digitized by Convergence, which creates the resulting platformconvergence. This is difficult not to follow this definition of the media, the business, and the news technologies as all progress has revolutionized the mass media.

Fagerjord and Storsul, according to [8] in Chao Chen [9,p. 186] it show that Convergence was an es sential label for the change process in the 1990s. According to him, the media is much more than just technology, and fusion in every areathey survey is not a suitable term. The idea was eventually related to the first wave of the Internet age. The explosive growth of ICT is currently indicated by the formation of online media. Already human civilization has an influence on media, it should be said, which is alsoovergrown, rapid, and instantaneous. The Internetpresence, which provides different information and news, is beginning to overcome print media popularity s lowly. Many internet news pages deliver Without really being asked for news immediately.

It was widely known that the mass media had been criticized for the fact that its reports have a refractive tendency. Also, due to the interests of economic and political associations, the position of the media as a collective entity is contradictory. As McChesney and Nichols have argued [6,p.201], The cris is in journalismoutput is because it operates It leads to publicity under some profit-oriented media systems.

As Thurtlow has shown [4, p. 36], A worldwide networking network whose cables have Tapped territories and regions fundamentally changed business activities, helped to generate new forms of incidents, and overflowed cons umer awareness. Romance has developed over cable, and several users created and solved the secret code. Digital media was tried and not regulated by the government and regulators. In the meantime, a technical subculture emerges 
without the cable with its patterns and vocabulary. Thurtlow's example reveals that mains tream journalis m, initially aimed at improving society, Although, income shareholders gained and a media empire too was formed by the mass media.

Besides, modern journalis mhas been made a space for efforts to deceive by aligning the media with the power to implement various forms of hegemony. There are many mass media which are a means of propagating the dominant discourse via domination. The idea was distributed and aimed to become a popular concept in the minds of the people. In the meantime, it can be shown that meaning or other debate is diminished or opposed as deviant.

Modern journalismaims to adopt rational and realis tic concepts for progress in different fields as a form of hegemony in society. However, if the ratio and reality are the primary references to culture, there is an indication that the community will lose humankind. A paradox exis ts when people seek to achieve and improve their capacity to react to reality, but they have to eradicate human nature.

\section{Citizen Journalism Establishment}

Citizen journalis mis a regular practice in industrialized economies and only a handful are as s ociated with much the same topic in emerging regions. This segment explores the concept of citizen journalism as a new phenomenon, the opportunities and limitations of community journalis $m$ in Indonesia. The next post addresses the existing literature.

As a consequence of the growth of online journalis m, Citizens' Journalis mbecame created. The method of compiling, writing, editing, and disseminating the expression online will be called web journalism. Online journalismis characterized as reporting fac ts that are created and published on web networks. Compared to an online news release, digital media is a lot of material on the internet. The state of social media alerts, subject trends, virals and the distribution of media seems to have something new in journalism.

Citizen journalis mmay generally be described as civilians factual reporting that can meet other needs of the people at home. Citizen journalis mis als o an activity which is conducted out during the country, compiled, published, analysed and trans mitted by the people, not by journalis ts, whomcontribute meaningfully to facts and knowledge. Everything applies to the Bowman and Willis statement [10, p. 10], which defines journalism as a citizen "... the act of citizens playing an active role in the process of collecting, reporting, analyzing, and disseminating news and information".

The journalistic integrity of citizens is often seen as a individual or collective involved in the compilation, publishing, analyzes and distribution of news and information purpose of providing unbiased, detailed, broad-based and representative knowledge. [1] The interpretation helps us to understand that anybody will contribute to both the reporting and distribution of news in the media, mas s media and social media, including such websites, forums, facebook, twitter, youtube, etc.

The Online journalism throughout the context of online journalis $m$ has been created by online reporters. The Journalism Blog, including personal blogs and community news, smartphone journalis ts and tablets, social media journalism and websites, social networking platforms or pages on social media, publishing, content production and publishing, journalis m, and information.

Online journalism has formed the critical pillar of the idea of citizen journalis mby means of technical means for the activities of citizen journalism [4, p. 15] Computer-media communication (CMC) specializes more in interpersonal, transversal and web communication. 
Susan Herring explains in her review in the book Computing Mediated Communication that $\mathrm{CMC}$ means human contact by means of a computer device. The fact that $\mathrm{CMC}$ is a phase of human communication through computers that refers to a person in a particular context and participates in mediation processes for a variety of purposes is no different from John December, and that CMC can be defined as a communication between two or even more computer-mediated individuals. That the information and expertise people use to spread awareness on the internet through social media and to develop social media technologies like Facebook, Twitter, Instagram, and Youtube,, introduces new terms: citizens (call: warg anet) or netizen journalism.

Journalismis defined as a new phenomenon "... individuals carry out active activities in the process of collecting, reporting, sorting, analyzing, and distributing news and information ..." [11, p. 71]. Kelly (2009) Notice that these same words could have been used to define specific criteria for the activities of citizen journalism. Nevertheless, and it's most important to realize that Citizen Journalis mapplies to the effective involvement of citizens in the production and dissemination of knowledge. One of the main characteristics of citizens' journalism. The people who participated in the Internet network are the citizens in question, while people, participants, viewers are sometimes referred to differently by the world citizens.

Citizen journalismis indeed an activity that is conducted out during the country, compiled, published, analysed and disseminated by the people, not just by journalists, who contribute meaning fully to facts and knowledge. This relates to the Bowman and Willis phrase [10, p. 10], which defines citizen journalism as "... the act of citizens playing an active role in the process of collecting, reporting, analyzing, and disseminating news and information". Citizen journalismis also an activity that includes citizens or perhaps a collection of persons who deliberately gather, report, interpret and disseminate news and information aim of providing independent, accurate, accessible and democratic content [10, p. 110].

Also, the termcitizen journalism has several words and terminologies as journalis $m$ Public (Public Journalism), Journalism Advocacy (Advocacy Journalism), Journalism Participatory (Participatory Journalism), Media Participatory (Participatory Media), Reporting Open Source (Open Source Reporting), Journalism Distributed (Distributed Journalism), Media Citizens (Citizens Media), and Gras sroots Journalism(Gras sroot Journalism). Although there are several differences, the scope of the termprioritizes citizens as communicators and implementers who contribute directly to the news.

Citizen journalismbecame reported on 19 January 1998, in a news on the internet about the unfaithfulness of President Bill Drudge, although Bill Clinton and that one of his assistants, Monica Lewinsky who became the closest rememberers of the Monicagate Incident [12, p. 123]. Public journalis mis strongly connected with the idea of citizen journalis $m$ in the United States since the 1988 presidential election. The powerful contest between candidates for president led to the dominance of traditional media such as newspapers. Will not be of interest of the public, and sothere is public participation in the news business. Therefore it is called public media. Mass media pick the strategy and concern of the public.

Citizens' other participation in the production and delivery of news, but the change in reading passive to active users also happens [11]. Furthermore, Widodo [13] this encourages a citizen 's views on the manufacturer, the owner and asks the citizen can dap rather than just the passive user. The emergence of Citizens' Journalis $m$ due into either theirs colliding with traditional journalism.

The products of the writing of journalists who previously earned journalism education and have expertise and pieces of knowledge in the field of writing and writing ethics are news 
stories and news broadcast in traditional media. In Citizen Journalism, ordinary people, former pas sively consumers, and news providers could only createnews and stories on their own and become owners and actors of their press. This material could not be transmitted through conventional media outlets. Like when you make a blog, you write down your business expertise and travel and then broadcast it on the Internet.

In Widodo's view [13], Citizen Journalism said: (1) the Citizens Journals produces news, reports, analysis of news, remarks, and opinions, which are regularly updated by providing links in which readers can post comments. (2) The residents' report in production is published as the news that journalism has transparent follow-up values such as honesty, precision, balance, and objectivity. (3) This is not a formal approach, nor is not a personal one. (4) Offered by both trained and ordinary people in leis ure time, citizen journalism. (5) In addition to material written by flexibly screened citizens, residents of journalis mhave an editor focusing on es sential topics. (6) Not too sharp is the border between old and new. (7) When producing articles, users rely on their own (subject) view. Therefore, it can be inferred that everyone who is ordinary people, including every culture, does nothave journalistic skills, can do so with the Citizen Journalism activities.

\section{Start of modernity and postmodernism}

The term postmodern reporter reacts to modern journalis $\mathrm{m}$. The revolution is not always a chance. In a process that continues through many periods and times, the changes from contemporary to postmodernis m are incremental. Efforts to create hegemony through news and siding with capitalis mpose a kind of challenge for journalis m clearly understood as the media structures its institutions and act as media conglomerates in favor of capitalis $\mathrm{m}$. Until then, mainstreamjournalism has been more likely than successful in raising skepticis $m$.

Consequently, journalis mobviously can not be accepted as an ideal form. This is where postmodernism plays a big part. Thinking moves in a better way. As said by Lyotard, [14], knowns have undergone considerable changes due to the technological developments in the epoch of computer controlled society (information). Perception has stopped relying on s cience. Nonetheless, s chema-narratives like capitalist and marxis $m$ drive it, but als o create or develop the orientation of knowledge based on availability frombroad institutions such as capitalis mand marxism. This aims at gaining information. A revolutionary innovation takes place through digital technology (information) mostly on values of creation, use and transformations. In the economic field, social labour is being used less frequently in the environment of telecommunications, information is being speeded up, processed and information can be modified and information can alter and even manipulate reality.

Post-modernism is indeed an effort to create ideas to ultimately destroy modernity 's values. Postmodernis $\mathrm{m}$ is a challenge to the preceding genre, called modernis $\mathrm{m}$. The term postmodern is perceived to be s ome kind of liberation from different forms of oppression. And there is no truth in people. Everyone has a link within his or her viewpoints so that the advent of postmodernity emerges as a reaction and a critique of earlier opinions which, through ideas that had been considered faulty and failed, have produced various tyrannies of their own [14].

There is a broad perception, according to Ritzer, that the postmodern period is over; secondly, that postmodernismhas brought about the sh change of new goods in the field of culture [15]. New media is really a technological innovation phase, wherein the general consciousness is expansive and distributed, which can not be regulated by a single form of hegemony, such that the exis tence of new media contributes to postmodernist conceptions wherein the they try to escape thems elves from the various meta-narratives brought on by capitalis $m$ and Marxism. 
Numerous facets of human existence improved and separated the constant exchange of knowledge and technological evolutions. Modernization redefines certain parts of life. That would be a very drastic change in the lives of individuals to create the Internet. The meaning of journalismhas changed; the nature and scope of its function has also greatly expanded, extensively in the areas of communication. With the emergence of online media, web exploration made a significant revolution in the world of media.

To Marx, the root of modernismis culture, which Habermas then adapts as the source to contact ratios $[15$, p. 669]. The rate is considered as the only force which sets out all humanitarian concerns. In all philanthropic activities, giving priority to connections includes understanding human types. Modernismmay also be translated as a spirit to seek and dig for the reality, the actual reality, the absolute truth of all the universe. The ratio of humanity is considered capable of researching evidence to discover fundamental truth laws.

Postmodernism has values that can change social conditions, human behavior, and understanding of all facts in various sectors based on the status of late modernism. The critical postmodern attempt is to reject the grand tale, which appears in the modern world, mixing reas on with glorious reason and making roomfor any little story which occurs later in life, in the local territory, and diversity of different opinions.

In several aspects of science and technology, postmodernism criticizes perceived modernism led to the centralization and universalization of ideas. Postmodernism is not a finishing point of innovation, but a new condition. The supremacy of a great story is modernity to Lyotard. However, most big narrative ventures fail, such as communism. Lyotard argues that the "war" on such a totalistic perspective is now the right moment.

\section{Rese arch Methods}

They are using the approach of evaluation and literature study. Researchers have tried several website searches of citizens' journalism websites in Indonesia. Try to make observations about different phenomena and to describe them in various literature, based on different is sues. Jalaluddin said that [16, p. 25], significance of the impact is intended to gather in-depth information regarding the current phenomena; to identify the is sues and to analyze specific circumstances or methods; to carry out observations or as sessment tools; to decide what these other people are doing at around the same phenomenon.

Analysis uses data in journals, online databases in the review of the literature. The researcher did so in a qualitative way. This method looks at and studies different human symptoms, pathologicaland necessary side effects, wherein the scientists perform work on many websites, forums, so on and so forth. Nazir suggests, therefore [7, p. 156] can say that as field study, the study is in. This research is qualitative and has interpretive tendencies, using many methods for the analysis of is sues through phenomena considered. Muly ana, according to [17, p.4], The application of several techniques, often called triangulation, is aimed at making researchers understand the studied phenomenon fully.

The computer technology competence concept must have been utilised in this research, which es pecially clarified the essence of the process that in all cultures it can be transmitted or done by anyone. According to the above theory, new technologies will build a new culture and make people by having thought and behaving in society - a technologist I, who used to be an immediate person in every movement of technology change. With regard to technology dependenton communication, cultural interaction is stronger than that of any technological shifts that can impact human lives and indeed human behaviour. 


\section{Results and Discussion}

\section{As postmodern journalism, citizens ' journalism}

Journalism continues to grow and has an existence with democracy that certainly requires different media in all democracy formed. A s pokesman for expres sing the interes ts of citizens in Civil liberties protection. Journalis tic integrity became developed as an occupation with professional standards during the same period. Profes sionalis $m$ allows productive practice in print media. In truth, though, the current technological environment in the media has fundamentally changed. Although the concept of journalism is no doubt regarded as the profession that appears in the modern media, every pers on (Netizens) typically conducts multiple different activities.

There is really no problem with lack of citizens' capacity in journalis m to report. Citizens are not journalists that, as legitimation to everyones job role, uphold journalis tic guidelines. Nor are media people who, in effect, become a meta-narrative curriculum. To date, experience of journalis mhas indeed been legitimized in public media rather than in journalismas a wonderful story. The idea of food to grasp the prospect of modernity has shifted with the advent of social media. Communication technology enables citizens to transmit their data. Due to the information they obtain, people will be creators and publishers. Residents and researchers of information may be called journalists by their communication technologies.

Society is both an object and a topic of news in citizens ' journalism. You can be writers and simultaneously publish them. This is what makes every human being a social is sue. It is this era that gives an extraordinary contribution to others to a person in a mediocre group. Even if each otherdoesn't physically know one another. The above refers to Lyotard 's pers pective that demonstrates theimpact on the growth of science at the end of the 20th century. Significant advances and shifts in perception, research and technology have taken place in the information society $[14$, p. 44].

Through demonstrating their existence here anyway, the media are given as a form of critical citizens hip. The public funds made available are major component of the hopes and desires of the people. This identity is a mutual concept that supports the shared experience of service providers as people with rights and privileges. The social media alone have provided people with a way to create an positive public identity and enable themand actively participate throughout the decision-making process.

To make all forms of citizen journalis m, an alternative type of journalist practice. Anyone can be interconnected with anyone in new media. As Dan Gillmor said, a pioneer in the American public journalis m movement is the fundamental principle of accommodating the need to communicate with everyone: talking among themselves. Everybody wants to expres s their thoughts, anxieties, and hopes. All people wish to hear or read the beliefs, stres ses, and expectations of others and also to understand them. Moreover, there is also a strong desire to support others or at least to comment on the thoughts of others.

In Lyotard's words [14], Wisdomhas evolved in an information society age as a result of technical advances. The object of experience is therefore no doubt so there would be research. Nevertheless, capitalis ts ystemand Marxism have an impact on the metanarrative because then knowledge guidelines is built on the requirements of the two world institutions. Global transformation is underway through digitaltechnology, in order to produce, use and improve. Human power is being used in the economic field, telecom living room, rapid data proces sing, knowledge which can sometimes manipulate the reality, increasingly restricted, and computer 
society becomes more accessible, pluralist and democratic, with a transformative society nature.

There really are incredible advances in technology, training and research in a worldwide computerized society. A phenomenon called postmodernis mhas been created and updated in the culture. Over the last forty years, science and technology has been increasingly active, as well as language, theory of linguistics, communication, cybernet, computing and literature, trans lation, data storage and computer institutions. Technology transition impacts knowledge extensively. Acquiring, clas sifying, building and using experiences have changed every as pect of technology and its commercialization.

Within the field of information technology within specific, and according Lyotard, this status of awareness is how science is legalised, what something considers meta-narration, including liberty, development, the liberation of the proletariat, etc. However according Lyotard, the same fate as beforehas been witnes sed, for example faith, sovereign identities, westernillusions of dominance, etc. The same is happening in the journalistic world where journalis min Gadang Gadang represents a way or capacity to get information that reflects the truth; indeed, mass media have helped manage humanity in the past.

It provides a conceptual environment for the basic concept of digital world, which the individual slowly begins to understand. Such awareness contributes to excellent technological power. Humans are specifically innovation-controlled, but never the other way approximately. The pattern of these circums tances has added to the digital world a variety of ever-increasing new spaces. Each of them is a weblog, or a blog. Blogs start with a diary or magazine of someone online. In addition to the individual and up-to - date information, the blog offers a list of connections to other websites or blogs. The fact that each visitor can comment on what appears on their blog is another distinctive feature. The comments are open to other visitors, as well as feedback from the blog owner.

\section{In the direction of postmodernism}

The development of internet technology also marks the state of journalism. Journalism, as a citizen, is the new journalism. Each internet user can now free of chargecreate their media. The emergence of blogging groups and other forms of citizen journalism is a mass media backlash. Current practice has ev olved froms pecialist to regular journalis ts to naturally, interactively and more frequent interactions with traditional media. Lyotard-conforming [14], post-modern environments are a illus tration of new environments of awareness in many of these developed societies. Citizens in the industrialized post-industrial or emerging age. Lyotard mentioned the word pos tmodern to characterize the information needs of users and emphasize the complex complexity, the local / ethnic community, and everyday routines.

This is following the work carried out by Situsweb based on citizen journalis m called OhMyNews. However, it raises significant problems in the writing of ethics and the code of ethics in journalism. Due to everyone without journalismknowledge and skills to present and publish their journalistic work thems elves. The question then is how socially, economically, politically, and culturally our work and interactions in citizens ' publishing networks - and, at least as passive users - benefit our everyday environment. News in the world, as it is, is plentiful with information on many sides and may notbe just one face because everyone has the opportunity, in the context of a joint dialog with the principle of public journalis $m$, to interpret and interpret events.

Lyotard says, however, that society would be not only technologically dependent but also language and voice. Thus, Ly otard is the subject of the involvement of narratives in our social lives. Religious guidelines and help in building social order in non-indus trial societies include 
myth and tales (fables, etc.). A new generation of theories, science, has arisen in this age of light which has pushed for theideas of development, causes, science and technology which will liberate mankind fromthe battles of chaos, ignorance and injustice. Each tale aims at achieving social objectives. Through the novel, the current socialorder is legitimized and a framework is given to as sess human activities.

Such is sues get their place in the online world, forums, and even citizens' journalis m. In the early 1990s, a modern wave in journalis morig inated in the USA. There is no exact information as to who started it, as pers onal claims still exist without a comprehensive interview. Yet, at that time, the era of its appearance was real. The type and design are always subjective and are all based on a blog application, depending on the desires of each author. One thing is sure: there is and emerges a culture of participatory journalis $\mathrm{m}$. This is als o the principal attribute of public journalis $m$. This included the journalis tic work carried out by the general public and publis hed online rather than professional journalists, and comments from other users.

In citizen journalis $m$, the basic idea is that the public should always be viewed as a news source, not just passive viewers so that this is part of traditional mainstream media-based journalis $m$. In other words, there has been s o much fluidity between journalists as reporters and news writers, speakers as the sources of the news and the viewer as news consumers. It is no longer possible to identify inflexibly between producers and consumers because both can be played by everyone. Necessarily, interaction and interconnection are the priority of citizens ' journalis m. Moreover, other citizen journalism's underlying concept is that news is a shared building tool between journalists and readers. If the correspondence was previously only viewed by the mas s media as an occurrence. Today, by citizenship, the news finds its sense.

The coverage is no doubt an elitis mthat is dictated either by the major media or by a limited journalists' party. You through writing it to a websites that seems to have a civic journalism concept if you have a living story and als o have an impact on society. In truth, thenews in mass media is not a social reality. Alternatively, a cycle of building on social truth has also taken place of media life. Nevertheless, only press editors were interested in the building process. Or, in other words, he 's definitely elitist. The mas s media decides what has to be reported and what leaks from covering events. Press also maintains the reader's appreciation for the news.

The theory of civic journalis min the cyber world decons tructs this trend. Everyone goes back to the original definition of the news itself, i.e., all that others want and need to know. The press not only shares knowledge with the public through their story but also turns the environment into a forumfor contact between people and a productive place for dialog. News is a study by people and maybe subjective but can be a means of dialog to bring together life's theory and synthesis.

The critical role of democracy in the press lies in the degree to which media have become a public sphere: an environment which is free of dominant politics and capitalists' economic interes ts, which allows for fair and open discussion on general is sues that impact on people's lives. A broad community-based networking facility enables the dis semination of facts and views is the essence of public space. A basis for collective political actions can be developed in the area consisting of a stock of general knowledge. In public spaces, a social space can be created without restrictions for free general discussion. Journalis $m$ then builds a community open s pace (civility) to fulfill citizen s' rights, since the freed om of information flows empowers millions of people.

The media should, therefore, be expressed as a medium of democracy. The media is, therefore, not a tool for the perpetuation and profit-making of the interests of media corporations. The ideology of the national press is the foundation of the fourth democracy (the 
fourth justicepillar), making it impos sible to establis h media conditions subject to market law. In the hysteria of giant media-capitalis ts the importance of the public in accurate, credible, unbiased and true facts aimed at informing and educating people disappear The media would als o be undermined by the enhancement and control of government and economic capitalists as the driving force of the political economy of capitalistic capitalis $\mathrm{m}$. This suggests that the liberalization of the press would alter the essence of journalis $m$ and of media content in the interests of the market.

Mas s media now only place consumers instead of citizens on the public or public. The main goal of the media is for owners and stockholders to benefit. Encourage audiences to take pleas ure, show advertisements, and buy goods. That's why the media find something that is common in culture to be appealing to the public. The ultimate aim of the media is therefore to promote active citizenship by means of awareness, education and social integration. Therefore, the extent of media popularity is actually profitable, not in the public interest.

Political economists, media, do not work in vacuum, but their progress depends on the political economy's interests. The explanations for the media boom are the fact that advertising profits are boosted. And Lyotard insists that the essence of information can not shift in the light of this essential transition. When theculture enters the area known as the postmodern era, the state of experience will change. Moreover, education is not an objective, but knowledge is a form of sale.

The momentum of liberalizing broadcast media markets, especially in recent years, will only challenge the national press liberty standard that national press still enjoys and hinder the ongoing democratic process that media requires as a platform for information, education and civic empowerment. In reality, national private television was an instrument of commercialization and provocation, rather than a medium to learn and educate the public. It was through promoting the culture of consumption, the violence, the manipulation of eroticism, and mysticis $m$ that rationality broke out.

This reveals that mass media is not only a en vironment in which social as pects are ignored, but also a forum for the hegemony of political and economic rulers. The media are an ideological instrument that perpetuates public hegemony which is only seen as consumers through ownership patterns and presented goods. The media also contributes to the advancement of market-based legislation by raising public opinion.

\section{Conclusions}

Conditions have changed; old media statements have to be checked. Journalis m may still be called reality technology, but early findings will not be adequately definitive since circumstances differ greatly. Unlike monopolies of past encounters in media, which have already lost their dominant positions as technological changehas increased, media, as the key determinant of news, has also lost its power as reality. Journalism faces considerable difficulties in tackling politicalins tability. Given the on -going efforts of journalis mto improve its image as a fair, equal and noble organization, society views reporters differently.

For work as a single entity, media is too difficult to break into many organisations with various economic structures, technical ideas and news standards. Modern journalism criticisms really should be controlled for normative purposes, potentially shifting to antidemocratic viewpoints more clos ely to populis m than to democratic different viewpoints that encourage empathy, truth, lis tening and communication. Wecan not create further democracy, but authoritarian rule by dis suading a technocratic knowledge system. Those counterepistemic replacements are restrictive and not democratic, es pecially progressive, types of modernist liberal journalis $\mathrm{m}$. We need to re-evaluate media practices. 


\section{References}

[1] A. Athique, Digital Media and Society: An Introduction, Cambridge: Polity Press, 2013.

[2] S. Biagi, Media Impact, an Introduction to Mass Media, Wadswortd: Cengage Learning, 2010.

[3] S. Bowman and C. Willis, We Media:How Audiences are Shaping the Future of News and Information, The Media Center: American Press Institute, 2003.

[4] T. Flew, New Media, 4th ed., Australia: Oxford University Pres s, 2014.

[5] J. C. Foust, Online Journalism: Principle and Practices of News for The Web, London: Routledge, 2011.

[6] Y. Irianto, Media Relation: Konsep, Pendekatan dan Praktik, Simbiosa Rektama Media, 2005.

[7] J. Lyotard, Kondisi Postmodern: Suatu laporan mengenai Pengetahuan (Edisi Terjemahan), Surabaya: Selas ar Surabaya Publishing, 2009.

[8] P. Messaris and L. Humphreys, Digital Media, Transformations in Human Communication, New York: Peter Lang Publishing, 2007.

[9] R. McChesney and J. Nichols, The death and life of American journalis m: The media revolution that will begin the world again, New York: Nation Books, 2010.

[10] D. Mulyana, Ilmu Komunikasi: Suatu Pengantar, Bandung: Rosda, 2001.

[11] G. R. Ritzer and D. J. Goodman, Teori Sosiologi: Dari Teori Sosiologi Klasik sampai Perkembangan Mutakhir Teori Sosial Postmodern, Yogyakarta: Kreasi Wacana, 2009.

[12] C. Thurlow and et.al, Computer-Mediated Communication, London: Sage Publication, 2004.

[13] L. Chao-Chen, "Convergence of new and old media: new media representation in traditional news," Chinese Journal of Communication, vol. 6, no. 2, p. 183-201, 22 April 2013.

[14] P. Dahlgren, "Media Logic in Cyberspace: Repositioning Journalism and its Publics," Repositioning Journalism and its Publics, vol. 3, no. 3, p. 59-72, 7 November 2014.

[15] N. Inkster, "Evolution of the Chinese Internet: Freedom and Control," Adelphi Series, vol. 55, no. 456, p. 19-50, 5 May 2016.

[16] J. Lasica, "Blogs and Journalism Need Each Other," Nieman Reports, pp. 70-74, 2003.

[17] M. Jaakkola, H. Hellman, K. Koljonen and J. Väliverronen, "Liquid Modern Journalism with a Difference," Journalism Practice, vol. 9, no. 6, p. 811-828, 17 July 2015.

[18] D. F. T. J. and A. D. Tyson, Social justice and rule of law: Addressing the growth of a pluralist Indonesian democracy, 2011, pp. 1-19.

[19] Y. Widodo, "The experience of NGOs in Indonesia to develop participatory democracy by the use of the internet," Internetworking Indonesia Journal, vol. 3, no. 2, pp. 35-48, $2011 \mathrm{~b}$.

[20] S. Wu, "When new media operates within a state-mediated press system: asses sing new media's impact on journalism crisis perceptions in Singapore and Hong Kong," Information, Communication \& Society, 2018.

[21] S. Waisbord, "Truth is What Happens to News," Journalism Studies, p. 1-13, 6 July 2018. 
